\title{
Characterization of an Amylase-sensitive Bacteriocin DF01 Produced by Lactobacillus brevis DF01 Isolated from Dongchimi, Korean Fermented Vegetable
}

\author{
Tae Kyu Kang and Wang June $\mathrm{Kim}^{1, *}$ \\ Nong Shim CO., LTD International Products Developmemnt Team, Seoul 156-709, Korea \\ ${ }^{1}$ Department of Food Science and Technology, Dongguk University, Seoul 100-715, Korea
}

\begin{abstract}
A DF01 strain that inhibits tyramine-producing Lactobacillus curvatus KFRI 166 was isolated from Dongchimi, a traditional Korean fermented vegetable, and identified as Lactobacillus brevis by biochemical analysis and reverse transcriptase sequencing of 16S rRNA. The antimicrobial compound produced by L. brevis DF01 was secreted at a maximum level of $640 \mathrm{AU} / \mathrm{mL}$ in late exponential phase in MRS broth, and its activity remained constant during stationary phase. The activity of bacteriocin DF01 was totally inactivated by $\alpha$-chymotrypsin, pronase $\mathrm{E}$, proteinase $\mathrm{K}$, trypsin, and $\alpha$-amylase, but not by catalase, which indicates the compound was glycoprotein in nature. The activity was not affected by $\mathrm{pH}$ changes ranging from 2 to 12 or heat treatment $\left(60,80\right.$, and $100^{\circ} \mathrm{C}$ for $\left.30 \mathrm{~min}\right)$, but was reduced after autoclaving. Bacteriocin DF01 had bacteriolytic activity and a molecular weight of approximately $8.2 \mathrm{kDa}$, as shown by tricine-SDS-PAGE analysis. Therefore, bacteriocin DF01 can be used in the manufacture of fermented meat products due to its inhibition of tyramine-producing L. curvatus and non-inhibition of $L$. sake, which is used as a starter culture for meat fermentation.
\end{abstract}

Key words: amylase-sensitive bacteriocin, Lactobacillus brevis, dongchimi

\section{Introduction}

Lactic acid bacteria (LAB) are widely used as starters in manufacture of fermented foods, such as yogurt, fermented sausages and vegetable, and provide beneficial effects for the sensory and hygienic quality of the final products. Most of them related to fermented foods have acquired the GRAS (Generally Regarded As Safe) status.

Wild bacterial strains need to create a competitive niche to survive in their hostile natural environment, so they often produce antimicrobial compounds. With regard this fact, LAB are focused on their antagonistic effects on food-borne pathogens and spoilage bacteria by organic acids, hydrogen peroxide, carbon dioxide, diacetyl, and bacteriocins (Schillinger and Lücke, 1989; Salminen et al., 2004).

Bacteriocins are a heterogeneous group of ribosomally synthesized antimicrobial peptides that usually inhibit the growth of microorganisms genetically closely related to

*Corresponding author: Wang June Kim, Department of Food Science and Technology, Dongguk University, Seoul 100-715, Korea. Tel: 82-2-2260-3373, Fax: 82-2-2260-3373, E-mail: wjkim @dongguk.edu producer strains by bactericidal or bacteriostatic effects (Klaenhammer, 1993). Some studies suggested that some bacteriocin-producing LAB or purified bacteriocins may be used as natural food preservatives since bacteriocins, which have proteinaceous nature, would be degraded in the gastrointestinal tract of man and animals (Eckner, 1992; Cleveland et al., 2001). The potential of using bacteriocins as preservatives could be achieved by using bacteriocin-producing bacteria as starters or by adding bacteriocins as food additives. The latter will necessarily need optimizations of their production because it is usually dependent on various strain-specific factors (LealSánchez et al., 2002). It was documented that these compounds are produced and secreted by almost all the bacterial species examined to date (Riley and Wertz, 2002).

Dongchimi is one of the water-based kimchi, Korean traditional fermented vegetable, fermented in brine by LAB. Recently, there are some interests to make Donchimi juice as soft drinks to promote human health due to its particular taste and anti-adipogenic activity (Ko et al., 1994; Ann, 2001; Kong et al., 2006).

Biogenic amines in food are synthesized by microbial decarboxylation of precursor amino acids (Ten Brink et 
al., 1990). Christensen et al. (1999) described that fermentative bacteria, like Lactobacillus spp., may catabolize amino acids to obtain energy in nutrient-limited environments. Biogenic amines, such as histamine, putrescine, tyramine, tryptamine, b-phenylethylamine and cadaverine, are considered as undesirable compounds due to their potential toxic effects attributed to vasoactive and psychoactive properties (Ten Brink et al., 1990) and due to an index of quality deteriorations in meat products because the longer meat products stored, the more contents of biogenic amines are formed during storage (Rokka et al., 2004). Cadaverine and putrescine, called as secondary amines, are much less toxic than histamine and tyramine, but they could be converted into carcinogenic compounds such as nitrosamines by nitorosation reaction during curing process (Saccani et al., 2005).

Many fermented foods such as salt-fermented fish products, fermented soybean products, and fermented vegetable products have been traditionally developed in Korea. Recently, it was reported that many fermented foods such as, cheeses (Gianotti et al., 2008), fermented sausage (Latorre-Moratalla et al., 2008), and sauerkraut (Kalaè et al., 2000) contained comparable contents of biogenic amines. For that reason, Korean fermented foods are likely to contain biogenic amines. Therefore it is necessary to examine the contents of biogenic amines in those foods and to investigate the relationship between those foods and biogenic amine-producing bacteria.

The initial bacteriological composition and population in food are critical factors influencing formation of biogenic amines (Bover-Cid et al., 2000; Kalaè et al., 2000). Therefore, the aim of this study was to isolate bacteriocin-producing $\mathrm{LAB}$ from dongchimi and its characteristics. We expect the bacteriocin which inhibits biogenic amine-producing bacteria could contribute to decrease contents of biogenic amines in fermented foods as an agent used to control the bacteriological composition and population.

\section{Materials and Methods}

\section{Bacterial strains used in this study}

All microorganisms were stored in $15 \%$ glycerol stock at -60 until required, and subcultured twice in appropriate broth before use. The media used in this study were as follow; Lactobacilli MRS Broth (Difco, Sparks, MD, USA), Nutrient Broth (Acumedia Manufacturers, Inc., Lansing, MI, USA), Brain Heart Infusion Broth (Acumedia Manufacturers, Inc., Baltimore, MD, USA), Tryptic
Soy Broth (Difco), and Reinforced Clostridial Medium (Difco). LB (Luria Bertani) broth, YM broth, and LBS (Lactobacillus selective medium) broth were made in our laboratory according to the Difco ${ }^{\mathrm{TM}}$ and $\mathrm{BBL}^{\mathrm{TM}}$ Manual.

L. brevis DF01 was isolated from dongchimi and the other microorganisms were purchased from ATCC (American Type Culture Collection, Rockville, MD, USA), IFO (Institute for Fermentation of Osaka, Osaka, Japan), KCCM (Korean Culture Center of Microorganisms, Seoul, Korea), or KCTC (Korea Collection for Type Cultures, Daejeon, Korea), or obtained from KFRI (Korea Food Research Institute, Songnam, Korea), and they are listed in Table 1.

\section{Isolation and identification of bacteriocin-produc- ing LAB}

Dongchimi was purchased from a local market and putative bacteriocin producers were isolated using a modified sandwich method, also called triple agar layer method, developed by Kim et al. (1993). The $0.1 \mathrm{~mL}$ of sample serially diluted was pour-plated with $5 \mathrm{~mL}$ MRS bottom agar (1.5\%), left to solidify, overlaid with MRS soft middle agar $(0.75 \%)$, and incubated at $37^{\circ} \mathrm{C}$ for $24 \mathrm{~h}$. The plates were overlaid with $5 \mathrm{~mL}$ of MRS agar seeded with L. curvatus KFRI 166 as an indicator bacterium $\left(\leq 10^{7} \mathrm{CFU} / \mathrm{ml}\right)$ and incubated at the same condition above. The colonies which showed inhibition zone against indicator bacteria were transferred on three MRS plates, one of them was for master plate and the others are for deferred and simultaneous assays. The number of indicator L. curvatus KFRI 166 in $5 \mathrm{~mL}$ of MRS top agar was ca. $\leq 10^{7} \mathrm{CFU} / \mathrm{g}$ and incubated at the same condition above. The colonies which showed inhibition zone against indicator bacteria were purified by streaking on MRS plate and each colony was confirmed using agarwell diffusion assay. For ager-well diffusion assay, $L$. brevis DF01 was cultivated in MRS broth at the same condition above, and the culture was centrifuged at $10,000 \mathrm{~g}$ for $15 \mathrm{~min}$. The supernatant was neutralized to pH 6.2 with $3 \mathrm{~N} \mathrm{NaOH}$ and filtered by membrane filter (pore size of $0.20 \mu \mathrm{m}$, ADVANTEC DISMIC-13CP, Toyo-Rochi, Tokyo, Japan). Each aliquot of $100 \mu \mathrm{L}$ of cell-free supernatant was placed into wells (diameter of $0.8 \mathrm{~mm}$ ) of the agar plate pre-inoculated with indicator strains $\left(\leq 10^{7} \mathrm{CFU} / \mathrm{g}\right)$, and the plates were kept at $4^{\circ} \mathrm{C}$ for $4 \mathrm{~h}$ to allow for diffusion before incubation.

Isolated strains were identified by Gram staining, a catalase test, morphology, and carbohydrate fermentation pattern using the API 50 CHL kit (BioMrieux, Marcy 
Table 1. Antimicrobial spectrum of $L$. brevis DF01.

\begin{tabular}{|c|c|c|c|c|c|}
\hline \multirow{2}{*}{ Microorganism } & \multirow{2}{*}{ Media } & \multirow{2}{*}{$\mathrm{Temp}\left({ }^{\circ} \mathrm{C}\right)$} & \multicolumn{3}{|c|}{ Inhibition $^{1)}$} \\
\hline & & & $\mathrm{SA}$ & DA & ADT \\
\hline Aeromonas hydrophila ATCC 7966 & NA & 30 & - & - & - \\
\hline Bacillus cereus KCTC 3624 & NA & 30 & - & + & - \\
\hline Bacillus mycoides KCTC 3453 & NA & 30 & - & - & - \\
\hline Bacillus natto KFRI 170 & NA & 30 & - & + & - \\
\hline Bacillus subtilis KCTC 2023 & NA & 35 & - & + & - \\
\hline Bacillus thuringiensis KCTC 3452 & NA & 30 & - & + & - \\
\hline Escherichia coli ATCC 25922 & LB & 37 & - & . & - \\
\hline Escherichia coli O157:H7 ATCC 23514 & LB & 37 & - & - & - \\
\hline Lactobacillus acidophilus KCTC 3179 & MRS & 37 & - & - & - \\
\hline Lactobacillus bulgaricus IFO 3533 & MRS & 37 & - & - & - \\
\hline Lactobacillus casei KFRI 704 & MRS & 37 & - & - & - \\
\hline Lactobacillus curvatus KFRI 166 & MRS & 37 & + & +++ & +++ \\
\hline Lactobacillus delbrueckii KFRI 154 & MRS & 37 & - & - & - \\
\hline Lactobacillus sake ATCC 11506 & MRS & 37 & - & - & - \\
\hline Leuconostoc mesenteroides ATCC 10830 & MRS & 37 & - & - & - \\
\hline Listeria innосиа АТСС 33090 & $\mathrm{BHI}$ & 37 & - & - & - \\
\hline Listeria monocytogenes KCTC 3569 & BHI & 37 & - & . & - \\
\hline Pediococcus acidilactici IFO 3884 & MRS & 37 & - & ++ & - \\
\hline Pediococcus pentosaceus KFRI 834 & MRS & 37 & - & - & - \\
\hline Propionibacterium acnes KCCM 41747 & $\mathrm{RCM}$ & 37 & - & - & - \\
\hline Pseudomonas aeruginosa ATCC 27853 & NA & 37 & - &.+ & - \\
\hline Salmonella enteritidis KCCM 12021 & NA & 37 & + & +++ & - \\
\hline Salmonella typhimurium KCTC 1925 & NA & 37 & + & ++ & - \\
\hline Shigella flexneri ATCC 12022 & NA & 37 & ++ & +++ & - \\
\hline Staphylococcus aureus ATCC 13565 & NA & 37 & - & - & - \\
\hline Staphylococcus aureus KCTC 3881 & NA & 37 & - & - & - \\
\hline Staphylococcus epidermidis KCTC 3958 & NA & 37 & - & - & - \\
\hline Streptococcus mutans ATCC 25175 & BHI & 37 & - & ++ & - \\
\hline Yersinia enterocolitica ATCC 23715 & TSA & 37 & - & - & - \\
\hline Candida albicans ATCC 13264 & YM & 25 & - & - & - \\
\hline Saccharomyces cerevisiae ATCC 13264 & YM & 25 & - & - & - \\
\hline
\end{tabular}

Abbreviations: BHI, Brain Heart Infusionagar; LB, Luria Bertani agar; MRS, Lactobacilli MRS agar; NA. Nutrient agar; RCM, Reinforced Clostridial Medium agar; TSA, Tryptic Soy Agar; YM, YM agar.

${ }^{1)}$-, absenceofinhibitionzone; +, 1 to $10 \mathrm{~mm}$; ++, 11 to $20 \mathrm{~mm}$; +++, above $21 \mathrm{~mm}$ (diameterofinhibition zone); SA, Simultaneous Assay; DA, Deferred Assay; ADT, agar-well-diffusion test.

I'Etoile, France). And the identity of the isolate was confirmed by reverse transcriptase sequencing of 16S rRNA (Macrogen, Inc., Seoul, Korea)

\section{Growth kinetics and bacteriocin production of $L$. brevis DF01}

MRS broth was inoculated with L. brevis DF01 (1\% of inoculum) of an overnight culture and incubated at $37^{\circ} \mathrm{C}$. The viable cell count (CFU/g), changes in $\mathrm{pH}$, and bacteriocin activity $(\mathrm{AU} / \mathrm{mL})$ against $L$. curvatus KFRI 166 using agar-well diffusion assay were recorded every two hours for $36 \mathrm{~h}$. Arbitrary units $(\mathrm{AU} / \mathrm{mL})$ were defined as the reciprocal of the highest dilution at which the growth inhibition was detectable.

\section{Antimicrobial spectrum of $\boldsymbol{L}$. brevis DF01}

Three methods (simultaneous, deferred, and agar well diffusion assays) were used to determine antimicrobial activity of $L$. brevis DF01. The antimicrobial activity against indicator strains was demonstrated by measuring diameter of clear zone around the well.

\section{Induction of bacteriocin activity}

According to the method of previous study (Rojo-Bezares et al., 2007), L. brevis DF01 was co-cultivated with heat-treated $\left(55^{\circ} \mathrm{C}\right.$ for $60 \mathrm{~min}$ or $100^{\circ} \mathrm{C}$ for $15 \mathrm{~min}$ ) or autoclaved $\left(121^{\circ} \mathrm{C}\right.$ for $\left.20 \mathrm{~min}\right)$ indicator bacteria, or cellfree supernatant of indicator bacteria. The initial bacterial concentrations of the L. brevis DF01 and heat-killed indi- 
cator bacteria were $10^{8} \mathrm{CFU} / \mathrm{g}$ and $10^{7} \mathrm{CFU} / \mathrm{g}$, respectively. Cell-free supernatants were obtained and submitted to agar-well diffusion assay to evaluate induction of antimicrobial activity against indicator bacteria.

\section{Effect of enzymes, pH, heat and detergents treat- ments}

Each aliquot of cell-free supernatant was treated with $0.1 \mathrm{mg} / \mathrm{mL}$ of $\alpha$-amylase, $\alpha$-chymotrypsin, catalase, pronase $\mathrm{E}$, proteinase $\mathrm{K}$, and trypsin according to the suppliers' instructions. All enzymes were purchased from Sigma-Aldrich (St. Louis, MO, USA). To test thermal stability, cell-free supernatants were adjusted to $\mathrm{pH} 6.2$ and each aliquot was heated 60,80 , or $100^{\circ} \mathrm{C}$ for $10 \mathrm{~min}$ or $30 \mathrm{~min}$, or autoclaved $\left(121^{\circ} \mathrm{C}\right.$ for $\left.15 \mathrm{~min}\right)$. Sensitivity to different $\mathrm{pH}$ values was examined by adjusting cellfree supernatants to different $\mathrm{pH}$ values ranging from $\mathrm{pH}$ 2 to $\mathrm{pH} 12$ with $3 \mathrm{~N} \mathrm{HCl}$ of $3 \mathrm{~N} \mathrm{NaOH}$, and then the samples were incubated at $37^{\circ} \mathrm{C}$ for $2 \mathrm{hr}$. These samples were readjusted to $\mathrm{pH} 6.2$ before antimicrobial activity test. The effect of detergents on the bacteriocin was tested by adding Tween $20(1 \%$, w/v, final concentration), Tween $80(1 \%, \mathrm{w} / \mathrm{v})$ and sodium dodecyl sulphate (SDS, $1 \%$, $2 \%, \mathrm{w} / \mathrm{v})$. After completing each of four treatments, the remaining activity was determined by agar-well diffusion assay.

\section{Mode of action}

MRS broth $(160 \mathrm{~mL})$ was inoculated with an overnight culture of L. curvatus KFRI 166 ( $1 \%$ of inoculum) and incubated at $37^{\circ} \mathrm{C}$. Forty $\mathrm{mL}$ of bacteriocin-containing cell-free supernatant neutralized to $\mathrm{pH} 6.2$ were added when the growth of L. curvatus KFRI 166 reached early exponential phase $(6 \mathrm{~h}$ old). Each of samples was taken every $1 \mathrm{~h}$ to determine optical density value under $600 \mathrm{~nm}$ wavelength using spectrophotometer (Smart Plus SP-1900PC, Woongki Science, South Korea).

\section{Molecular weight determination of bacteriocin DF01}

L. brevis DF01 was inoculated in $200 \mathrm{~mL}$ of LBS (Lactobacillus selective medium) broth ( $2 \%$ of inoculum) and incubated at $37^{\circ} \mathrm{C}$ for $24 \mathrm{~h}$. Cells were harvested by centrifugation (Sorvall RC-5C Plus, Dupont Co., USA) at $6,000 \mathrm{~g}$ for $10 \mathrm{~min}$ at $4^{\circ} \mathrm{C}$. The bacteriocin in the supernatant was precipitated by adding ammonium sulfate to $70 \%$ saturation and gathered by centrifugation under the same condition as above. The precipitate was resuspended in $10 \mathrm{~mL}$ of $25 \mathrm{mM}$ ammonium acetate buffer
(pH 6.5), desalted by using a 1200 molecular weight cutoff dialysis sack (Sigma-Aldrich, St. Louis, MO, USA), and submitted to filtration through a $0.20 \mu \mathrm{m}$ pore size membrane filter (ADVANTEC DISMIC-13CP, ToyoRochi, Tokyo, Japan).

The proteins in the concentrated supernatant were visualized using Tricine-SDS-PAGE, described by Schägger (2006), because this method was effective for the resolution of proteins smaller than $30 \mathrm{kDa}$. The sample was reduced by mercaptoethanol, incubated at $37^{\circ} \mathrm{C}$ for $15 \mathrm{~min}$, and subjected to SDS-polyacrylamide gel electrophoresis (Ezcell electrophoresis system, Komabiotech Inc., Seoul, Korea). The $10 \mu \mathrm{L}$ of sample was loaded on wells of $13 \% \mathrm{~T}$ and $3 \% \mathrm{C}$ acrylamide gels $(1.0 \mathrm{~mm}$ thick, without SDS for silver staining) overlaid with $4 \% \mathrm{~T}$ and $3 \% \mathrm{C}$ of stacking gel; $\mathrm{T}$ is the total acrylamide concentration and $\mathrm{C}$ is the cross-linker concentration. The gels were run at $30 \mathrm{~V}$ until the dye of sample buffer reached the bottom of stacking gel, after that, volt was raised to $90 \mathrm{~V}$ and carried out until the dye moved out of the gel.

After completion of electrophoresis, the gels were cut into two pieces; one is for silver staining described by Schägger (2006), and the other is for gel overlay assays as described previously (Bhunia et al., 1987).

For gel overlay assays, the gels were fixed for $2 \mathrm{~h}$ in fixing solution (10\% acetic acid, $50 \%$ methanol, $100 \mathrm{mM}$ ammonium acetate), rinsed three times over $2 \mathrm{~h}$, stored overnight in $\mathrm{ddH}_{2} \mathrm{O}$ at $4^{\circ} \mathrm{C}$, overlaid with $10 \mathrm{~mL}$ of MRS soft agar $(0.75 \%$ agarose) seeded with $L$. curvatus KFRI $166\left(\leq 10^{7} \mathrm{CFU} / \mathrm{g}\right)$ and incubated at $37^{\circ} \mathrm{C}$ for $36 \mathrm{~h}$.

\section{Results}

\section{Identification of bacteriocin-producing LAB}

Strain DF01 was isolated from dongchimi and exhibited an antimicrobial activity against L. curvatus KFRI 166 . Isolate DF01 showed Gram positive, rod shape, catalase negative, and lowered to $\mathrm{pH} 4.30$ at their stationary phase, and it was tentatively identified as L. brevis based on biochemical test by API 50 CHL kit (99.4\% identity). This isolate was further analyzed by sequencing of $16 \mathrm{~S}$ rRNA and was determined by L. brevis DF01 (Fig. 1).

\section{Growth and antimicrobial activity of $L$. brevis DF01}

Fig. 2 shows the growth profile of L. brevis DF01 grown in MRS broth at $37^{\circ} \mathrm{C}$ and antimicrobial activity against L. curvatus KFRI 166 by agar-well diffusion assay. The viable cell counts were increased from $8 \times 10^{6}$ 

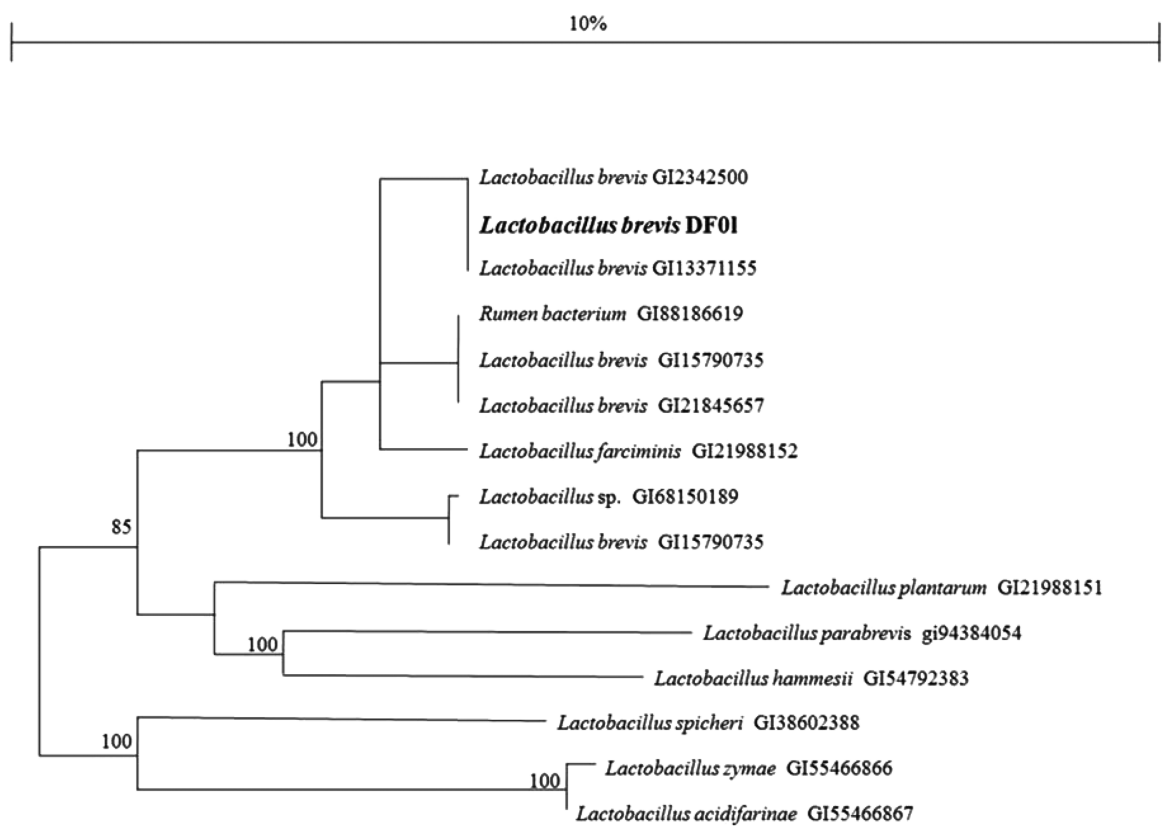

Fig. 1. Phylogenetic analysis of sequence from the 16S rRNA gene from isolate DF01; GI indicates Geninfo Identifiers numbers.

to $2 \times 10^{9} \mathrm{CFU} / \mathrm{g}$, and $\mathrm{pH}$ of the MRS broth decreased from $\mathrm{pH} 6.29$ to $\mathrm{pH} 4.30$ for 34 h. L. brevis DF01 started to produce bacteriocin DF01 extracellularly at $4 \mathrm{~h}$ during early exponential phase. The highest antimicrobial activity $(640 \mathrm{AU} / \mathrm{mL})$ was recorded in late exponential phase ( $20 \mathrm{~h}$ after inoculation), and the $\mathrm{pH}$ was about 4.72 . The antimicrobial activity remained constant during the stationary phase.

\section{Bacteriocin assays}

Inhibitory spectrum of the bacteriocin produced by $L$. brevis DF01 is listed in Table 1. The inhibition zones appeared in the top soft agar layer inoculated with indicator bacteria in both simultaneous and deferred assays, which indicated that $L$. brevis DF01 produces a diffusible inhibitory substance(s). Inhibitions were observed against Lactobacillus curvatus KFRI 166, Salmonella enteritidis KCCM 12021, Salmonella Typhimurium KCTC 1925, and Shigella flexneri ATCC 12022 in simultaneous assay, and against Bacillus cereus KCTC 3624 , Bacillus natto KFRI 170, Bacillus subtilis KCTC 2023, Bacillus thuringiensis KCTC 3452, Lactobacillus curvatus KFRI 166, Pediococcus acidilactici IFO 3884, Pseudomonas aeruginosa ATCC 27853, Salmonella enteritidis KCCM 12021, Salmonella typhimurium KCTC 1925, and Shigella flexneri ATCC 12022 in deferred assay. Agar-well diffusion assay further performed to confirm whether the inhibitions were the results of bacteriocin, and showed

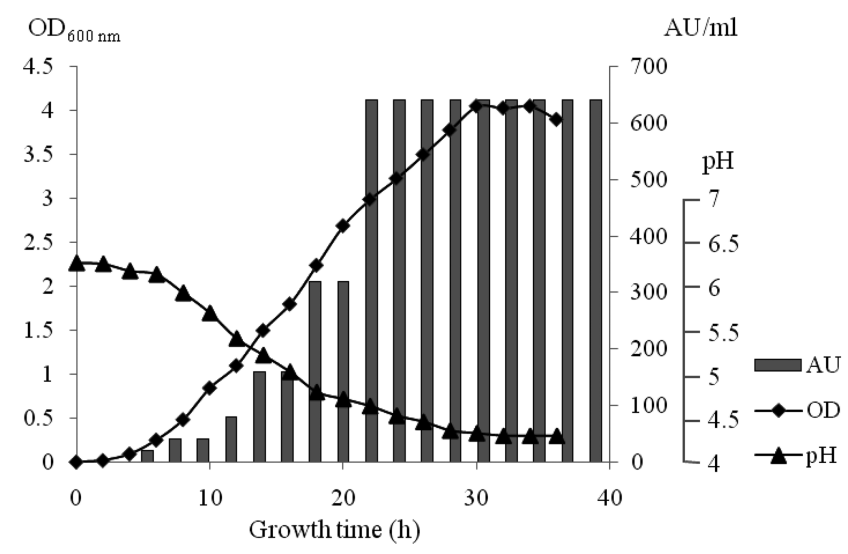

Fig. 2. Growth curve of $L$. brevis DF01 and its antimicrobial activity against $L$. curvatus KFRI 166.

that bacteriocin DF01 inhibited the growth of Lactobacillus curvatus KFRI 166 and Pediococcus acidilactici IFO 3884 .

\section{Induction of bacteriocin activity}

There was no change in antimicrobial activity between before and after co-culture with heat-treated $\left(55^{\circ} \mathrm{C}\right.$ for $60 \mathrm{~min}$ or $100^{\circ} \mathrm{C}$ for $\left.15 \mathrm{~min}\right)$ or autoclaved $\left(121^{\circ} \mathrm{C}\right.$ for 20 $\mathrm{min}$ ) indicator bacteria, or cell-free supernatant of indicator bacteria.

Effect of enzymes, $\mathrm{pH}$, heat and detergents on bacteriocin activity

The effects of physio-chemical properties on the stabil- 
Table 2. Physico-chemical stability of the bacteriocin produced by $L$. brevis DF01.

\begin{tabular}{lc}
\hline \hline Treatment & Bacteriocin activity \\
\hline Enzymes & - \\
ProteinaseK & - \\
PronaseE & - \\
Trypsin & - \\
$\alpha$-Chymotrypsin & + \\
$\alpha$-amylase & \\
Catalase & \\
PH & + \\
$2 \sim 12$ & \\
Heat & + \\
$60^{\circ} \mathrm{C}, 80^{\circ} \mathrm{C}, 100^{\circ} \mathrm{C}$ for $10 \mathrm{~min}$ & + \\
$60^{\circ} \mathrm{C}, 80^{\circ} \mathrm{C}, 100^{\circ} \mathrm{C}$ for $30 \mathrm{~min}$ & + \\
$121^{\circ} \mathrm{C}$ for $15 \mathrm{~min}$ & \\
Detergent $(\mathbf{m} / \mathbf{v})$ & + \\
SDS $(1 \%)$ & + \\
SDS $(2 \%)$ & + \\
Tween $20(1 \%)$ & + \\
Tween $80(1 \%)$ & + \\
\hline
\end{tabular}

ity of crude bacteriocin DF01 are summarized in Table 2. In short, the activity of bacteriocin DF01-containing supernatant was totally inactivated after treatments with proteolytic enzymes such as $\alpha$-chymotrypsin, pronase $\mathrm{E}$, proteinase $\mathrm{K}$ and trypsin, and also with $\alpha$-amylase, which gave the evidence of its glycoprotein nature. In contrast, no change in activity was observed after treatment of catalase, indicating the antimicrobial effect was not derived from hydrogen peroxide. In different $\mathrm{pH}$, heat, and detergent treatment experiments, the antimicrobial activity was not affected after incubation of supernatants containing bacteriocin adjusted to $\mathrm{pH} 2,3,5,7,9,11$, and 12 for $2 \mathrm{~h}$, incubation of supernatants heated at 60,80 and $100^{\circ} \mathrm{C}$ for 10 or $30 \mathrm{~min}$, and adding Tween $20(1 \%, \mathrm{w} / \mathrm{v})$, Tween 80 $(1 \%, \mathrm{w} / \mathrm{v})$, and $\operatorname{SDS}(1 \%, 2 \%, \mathrm{w} / \mathrm{v})$. The activity was partly decreased after autoclaving $\left(121^{\circ} \mathrm{C}\right.$ for $\left.15 \mathrm{~min}\right)$ of supernatant.

\section{Mode of action}

Addition of bacteriocin DF01-containing supernatant to the 6-h old culture of L. curvatus resulted in growth inhibition. The turbidity of indicator bacteria culture was decreased immediately after adding cell-free supernatant and the turbidity was determined by optical density value under $600 \mathrm{~nm}$ wavelength using spectrophotometer. The optical density $\left(\mathrm{OD}_{600 \mathrm{~nm}}\right)$ was decreased from 0.269 to 0.101 for $5.5 \mathrm{~h}$ (Fig. 3). The decreased turbidity means that bacteriocin DF01 has a bacteriolytic characteristic which induces killing by cell lysis.

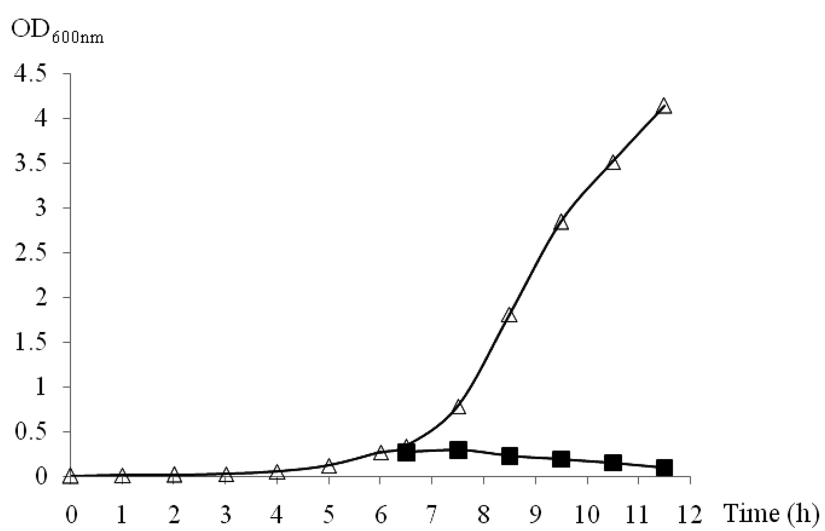

Fig. 3. Effect of bacteriocin DF01 on the growth of $L$. curvatus KFRI 166; Control (empty triangles) and treated cells (black squares) with crude bacteriocin DF01.

\section{Molecular weight of bacteriocin DF01}

Concentrated cell-free supernatant of L. brevis DF01 culture was separated by Tricine-SDS-PAGE and the gels were subjected to gel overlay assay. A band showed inhibition zone against $L$. curvatus KFRI 166 in overlaid plate, corresponding to molecular weight of about $8.2 \mathrm{kDa}$ (Fig. 4).

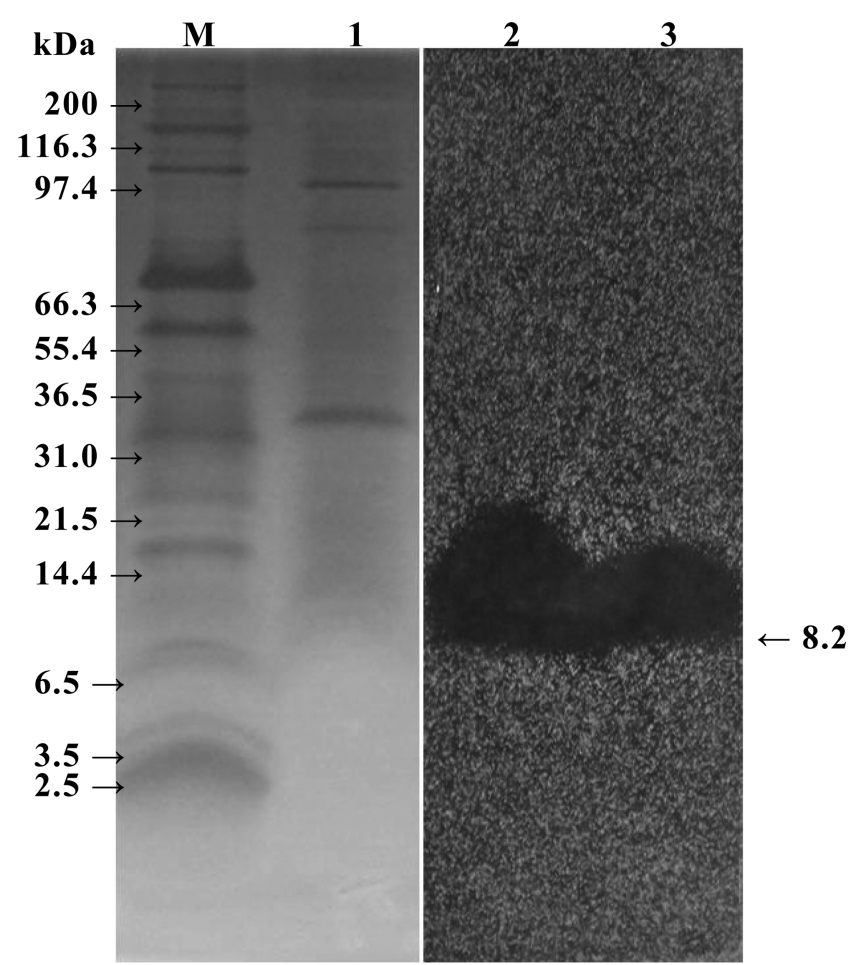

Fig. 4. Direct detection of bacteriocin DF01 from the concentrated supernatant by Tricine-SDS-PAGE; Lane M, molecular mass marker (Mark 12 ${ }^{\mathrm{TM}}$ Unstained Standard, Invitrogen) stained by silver nitrate; 1 , Concentrated bacteriocin stained by silver nitrate; 2 and 3 , overlaid onto plate seeded with $L$. curvatus KFRI 166. 


\section{Discussion}

The bacteriocin-producing LAB isolated from Dongchimi was identified as $L$. brevis. This bacteria was reported a strain of microbial composition in dongchimi in previous study (Kim and Kim, 1999).

The antimicrobial activity of L. brevis DF01 may be due to the production of organic acids which cause a consequent reduction in $\mathrm{pH}$ or due to the production of hydrogen peroxide, diacetyl, bacteriocins or bacteriocinlike substances (Schillinger and Lcke, 1989; Salminen et al., 2004). Hence antimicrobial activity of bacteriocin was confirmed by agar-well diffusion assay using neutralized supernatant of the L. brevis DF01 culture, and its proteinaceous nature was examined by treatments of enzymes. Bacteriocin DF01 was totally inactivated by proteolytic enzymes and $\alpha$-amylase. The sensitivity to $\alpha$ amylase implies the presence of an essential carbohydrate moiety with protein portion for its antimicrobial activity, therefore bacteriocin DF01 could be considered as a compound belonging to the fourth class of bacteriocins, as suggested by Klaenhammer (1993). However Nes et al. (1996) affirmed that the fourth class of bacteriocins has not yet been characterized adequately at the biochemical level, therefore they suggested recognition of this class seems premature. The following was the reason that plantaricin S produced by L. plantarum LPCO10 was first examined as a glycoprotein which was totally inactivated after $\alpha$-amylase treatment (Jiménez-Díaz 1993), but plantaricin $\mathrm{S}$ was confirmed that its bacteriocin activity was associated with two distinct peptides without carbohydrate moiety after purification by reverse-phase chromatography (Jiménez-Díaz, 1995), which means that cellfree supernatant containing glycoprotein bacteriocin should be further investigated after purification for its exact composition. Like the case of plantaricin S, bacteriocin DF01 should be also examined its characteristic after purification.

Bacteriocins which have glycoprotein nature were also reported by Lewus et al. (1992), Mathot et al. (2003), and Hernández et al. (2005); leuconocin S from Leuconostoc paramesenteroides, unnamed bacteriocin from Streptococcus thermophilus 580, and plantaricin TF711 from Lactobacillus plantarum, respectively. But there is no common characteristic in their antimicrobial spectrum, heat stability, and $\mathrm{pH}$ stability. Bacteriocin DF01 showed very narrow antimicrobial spectrum, while plantaricin TF711 inhibited gram-positive bacteria such as, Lactobacillus plantarum, Lactobacillus curvatus, Lactobacillus lactis, Clostridium sporogenes, and even gram-negative bacteria such as Shigella sonnei and Klebsiella pneumoniae. With regards to heat-stability and $\mathrm{pH}$-stability, bacteriocin DF01 was the most stable among these glycoprotein bacteriocins; the activity of leuconocin $\mathrm{S}$ was reduced by $75 \%$ after heat treatment $\left(60^{\circ} \mathrm{C}\right.$ for 60 $\mathrm{min})$, the bacteriocin produced by Streptococcus thermophilus 580 maintained its activity only up to $10 \mathrm{~min}$ at $60^{\circ} \mathrm{C}$, and plantaricin TF711 was led to complete inactivation by autoclaving $\left(121^{\circ} \mathrm{C}\right.$ for $\left.20 \mathrm{~min}\right)$ and incubation at above $\mathrm{pH} 11$.

Rojo-Bezares et al. (2007) described that the production of bacteriocin secreted by L. plantarum strain $\mathrm{J} 23$ was only detected when L. plantarum strain J23 was cocultured with intact cells or heated cells $\left(55^{\circ} \mathrm{C}\right.$ for $\left.60 \mathrm{~min}\right)$ of inducer strains (L. lactis MG1363, L. hilgardii J81, and $P$. pentosaceus FBB63), but not detected with pure-culturing of $L$. plantarum strain J23 and co-culturing with heated $\left(100^{\circ} \mathrm{C}\right.$ for $\left.15 \mathrm{~min}\right)$ or autoclaved $\left(121^{\circ} \mathrm{C}\right.$ for $20 \mathrm{~min}$ ) inducer strains. On the other hand, Mathot et al. (2003) found that the production of bacteriocin produced by $S$. thermophilus 580 was doubled by co-culturing with L. delbrueckii subsp. lactis. In our study, we designed the induction tests of bacteriocin activity, but there were not any positive results in this experiment. Therefore, we could reach a conclusion that $L$. brevis DF01 produce bacteriocin in constitutive way.

The optical density $\left(\mathrm{OD}_{600 \mathrm{~nm}}\right)$ of indicator bacteria culture was decreased after adding cell-free supernatant of $L$. brevis DF01, revealing that bacteriocin DF01 has a bacteriolytic characteristic which induces killing by cell lysis (Fig. 3). Some authors proposed that release of autolytic enzymes could be one of the reasons of bacteriocininduced cell lysis. In their studies, they subjected most bacteriocins are cationic, so they can displace the binding site between anionic polymers (teichoic and lipoteichoic acids) and autolytic enzymes (Bierbaum and Sahl, 1987; Jack et al., 1995). But bacteriocin DF01 showed a very narrow antimicrobial spectrum so its activity may specifically interact with receptors on sensitive bacteria.

The molecular weight of bacteriocin DF01 determined by Tricine-SDS-PAGE was approximately $8.2 \mathrm{kDa}$. Before this experiment, L. brevis DF01 was previously cultured in MRS, modified MRS without beef extract which was replaced by peptone, or LBS (Lactobacillus selective medium) broth. We compared resolutions of each of the three concentrated cell-free supernatants through Tricine-SDS-PAGE and the best resolution was obtained using the supernatant from LBS broth (data not 
shown). This should be the reason that LBS medium has less protein contents, which ease to purify the peptide.

In fermented meat products, $L$. curvatus and $L$. sake are found as predominant microorganisms. But some $L$. curvatus strains produce up to five different biogenic amines such as, tyramine, putrescine, phenylethylamine, tryptamine, and cadaverine (Straub et al., 1995; Bover-Cid et al., 2001). L. curvatus, thus, causes accumulation of biogenic amines within products. Hence Roig-Sagués and Eerola (1997) suggested $L$. sake strains which do not have any activities of amino acid decarboxylation could be more suitable than L. curvatus when it comes to using a starter in meat manufacture.

We can conclude that bacteriocin DF01 produced by $L$. brevis DF01 is a novel bacteriocin that have a good potential for an agent which can inhibit biogenic amineproducing bacteria in meat products, and we expect that it can lead to decrease of the contents of biogenic amines especially tyramine in manufacture of fermented meat product.

\section{Acknowledgement}

This study was supported by Youlchon Foundation (Nong Shim) and BT project (Dongguk University).

\section{References}

1. Ann, Y. G. (2001) Dongchimi fermentation for drinks. Kor. J. Food Nutr. 14, 46-51.

2. Bhunia, A. K., Johnson, M. C., and Ray, B. (1987) Direct detection of an antimicrobial peptide of Pediococcus acidilactici in sodium dodecyl sulfate-polyacrylamide gel electrophoresis. J. Ind. Microbiol. 2, 319-322.

3. Bierbaum, G. and Sahl, H. G. (1987) Autolytic system of Staphylococcus simulans 22: influence of cationic peptides on activity of $\mathrm{N}$-acetylmuramoyl-L-alanine amidase. J. Bacteriol. 169, 5452-5458.

4. Bover-Cid, S., Hugas, M., Izquierdo-Pulido, M., and VidalCarou M. C. (2001) Amino acid-decarboxylase activity of bacteria isolated from fermented pork sausages. Int. J. Food Microbiol. 66, 185-189.

5. Bover-Cid, S., Izquierdo-Pulido, M., and Vidal-Carou, M. C. (2000) Influence of hygienic quality of raw materials on biogenic amine production during ripening and storage of dry fermented sausages. J. Food Prot. 63, 1544-1550.

6. Christensen, J. E., Dudley, E. G., Pederson, J. A., and Steele, J. L. (1999) Peptidases and amino acid catabolism in lactic acid bacteria. Antonie Van Leeuwenhoek 76, 217-246.

7. Cleveland, J., Montville, T. J., Nes, I. F., and Chikindas, M. L. (2001) Bacteriocins: safe, natural antimicrobials for food preservation. Int. J. Food Microbiol. 71, 1-20.
8. Eckner, K. F. (1992) Bacteriocins and food application. Dairy Food Environ. Sanitation 12, 204-209.

9. Gianotti, V., Chiuminatto, U., Mazzucco, E., Gosetti, F., Bottaro, M., Frascarolo, P., and Gennaro, M. C. (2008) A new hydrophilic interaction liquid chromatography tandem mass spectrometry method for the simultaneous determination of seven biogenic amines in cheese. J. Chromatogr. A. 1185, 296-300.

10. Hernández, D., Cardell, E., and Zárate, V. (2005) Antimicrobial activity of lactic acid bacteria isolated from Tenerife cheese: initial characterization of plantaricin TF711, a bacteriocin-like substance produced by Lactobacillus plantarum TF711. J. Appl. Microbiol. 99, 77-84.

11. Jack, R. W., Tagg, J. R., and Ray, B. (1995) Bacteriocins of gram-positive bacteria. Microbiol. Rev. 59, 171-200.

12. Jiménez-Diaz R., Ruiz-Barba, J. L., Cathcart, D.,P., Holo, H., Nes, I.,F., Sletten K. H. and Warner, P. J. (1995) Purification and partial amino acid sequence of plantaricin $\mathrm{S}$, a bacteriocin produced by Lactobacillus plantarum LPCO10, the activity of which depends on the complementary action of two peptides. Appl. Environ. Microbiol. 61, 4459-4463.

13. Jiménez-Díaz, R., Rios-Sánchez, R. M., Desmazeaud, M., Ruiz-Barba J. L., and Piard, J. C. (1993) Plantaricins S and T, two new bacteriocins produced by Lactobacillus plantarum LPCO10 isolated from a green olive fermentation. Appl. Environ. Microbiol. 59, 1416-1424.

14. Kalaè, P., Špièka, J., Køížek, M., and Pelikáno, T. (2000) The effects of lactic acid bacteria inoculants on biogenic amines formation in sauerkraut. Food Chem. 70, 355-359.

15. Kim, J. H. and Kim, J. I. (1999) Identification and fermentation characteristics of lactic acid bacteria isolated from Dongchimi as starter for radish juice. Kor. J. Microbiol. 35, 307-314.

16. Kim, W. J., Hong, S. S., Cha, S. K., and Koo, Y. J. (1993) Use of bacteriocinogenic Pediococcus acidilactici in sausage fermentation. J. Microbiol. Biotechnol. 3, 199-203.

17. Klaenhammer, T. R. (1993) Genetics of bacteriocins produced by lactic acid bacteria. FEMS Microbiol. Rev. 12, 3985.

18. Ko, E. J., Hur, S. S., and Choi, Y. H. (1994) Development of ion beverage from Dongchimi product by reverse osmosis concentration. Kor.J. Food Sci. Technol. 26, 573-578.

19. Kong, C. S., Lee, S. H., Seo, J. O., Park, K. Y., and Rhee, S. H. (2006) Anti-adipogenic effects of dongchimi Nano juice in mouse 3T3-L1 adipocytes. J. Food Sci. Nutr. 11, 285-288.

20. Latorre-Moratalla, M. L., Veciana-Nogués, T., Bover-Cid, S., Garriga, M., Aymerich, T., Zanardi, E., Ianieri, A., Fraqueza, M. J., Patarata, L., Drosinos, E. H., Lauková, A., Talon, R., and Vidal-Carou, M. C. (2008) Biogenic amines in traditional fermented sausages produced in selected European countries. Food Chem. 107, 912-921.

21. Leal-Sánchez, M. V., Jiménez-Díaz, R., Maldonado-Barragán, A., Garrido-Fernández, A., and Ruiz-Barba, J. L. (2002) Optimization of bacteriocin production by batch fermentation of Lactobacillus plantarum LPCO10. Appl. Environ. Microbiol. 68, 4465-4471. 
22. Lewus, C. B., Sun, S., and Montville, T. J. (1992) Production of an amylase-sensitive bacteriocin by an atypical Leuconostoc paramesenteroides strain. Appl. Environ. Microbiol. 58, 143-149.

23. Mathot, A. G., Beliard, E., and Thuault, D. (2003) Streptococcus thermophilus 580 produces a bacteriocin potentially suitable for inhibition of Clostridium tyrobutyricum in hard cheese. J. Dairy Sci. 86, 3068-3074.

24. Nes, I. F., Diep, D. B., Håvarstein, L. S., Brurberg, M. B., Eijsink, V., and Holo, H. (1996) Biosynthesis of bacteriocins in lactic acid bacteria. Antonie van Leeuwenhoek 70, 113128.

25. Riley, M. A. and Wertz, J. E. (2002) Bacteriocins: evolution, ecology, and application. Annu. Rev. Microbiol. 56, 117-137.

26. Roig-Sagués, A. and Eerola, S. (1997) Biogenic amines in meat inoculated with Lactobacillus sake starter strains and an amine-positive lactic acid bacterium. Eur. Food Res. Technol. 205, 227-231.

27. Rojo-Bezares, B., Sáenz, Y., Navarro, L., Zarazaga, M., Ruiz-Larrea, F., and Torres, C. (2007) Coculture-inducible bacteriocin activity of Lactobacillus plantarum strain J23 isolated from grape must. Food Microbiol. 24, 482-491.

28. Rokka, M., Eerola, S., Smolander, M., Alakomi, H. L., and Ahvenainen, R. (2004) Monitoring of the quality of modified atmosphere packaged broiler chicken cuts stored in different temperature conditions B. Biogenic amines as quality indicating metabolites. Food Control 15, 601-607.

29. Saccani, G., Tanzi, E., Pastore, P., Cavalli, S., and Rey, M. (2005) Determination of biogenic amines in fresh and processed meat by suppressed ion chromatography-mass spectrometry using a cation-exchange column. J. Chromatogr. A. 1082, 43-50.

30. Salminen, S., von Wright, A., and Ouwehand, A. C. (2004) Lactic acid bacteria: Microbiological and functional aspects. Marcel Dekker, Inc., New York, pp. 375-395.

31. Schägger, H. (2006) Tricine-SDS-PAGE. Nat. Protoc. 1, 1622.

32. Schillinger, U. and Lücke, F. K. (1989) Antibacterial activity of Lactobacillus sake isolated from meat. Appl. Environ. Microbiol. 55, 1901-1906.

33. Straub, B. W., Kicherer, M., Schilcher S. M., and Hammes, W. P. (1995) The formation of biogenic amines by fermentation organisms. Z. Lebensm. Unters. Forsch. 201, 79-82.

34. Ten Brink, B., Damink, C., Joosten H. M., and Huis in't Veld, J. H. (1990) Occurrence and formation of biologically active amines in foods. Int. J. Food Microbiol. 11, 73-84.

(Received 2009.8.8/Revised 1st 2010.8.12, 2nd 2010.10.13/ Accepted 2010.10.16) 